\title{
HENRY MORE I ISAAC NEWTON O DZIAŁANIU MATERII - KONTEKST NEOPLATOŃSKI
}

\begin{abstract}
Streszczenie. Jednym z głównych wyzwań stojących przed filozofami przyrody XVII wieku było znalezienie odpowiedzi na pytanie, co sprawia, że materia w ogóle działa? Dziedzictwo 'materii pierwszej' i jej czystej potencjalności było wciąż żywe, a przyjęcie teorii korpuskularnej czy atomistycznej niewiele tu zmieniało, dominowało wciąż przekonanie o całkowitej bierności ciał. Ich działanie domagało się jakiegoś wyjaśnienia, które stanowiłoby odpowiednik arystotelesowskiej, niematerialnej i aktywnej, formy. Wydaje się, że jedną z tradycji filozoficznych, do których sięgano w poszukiwaniu takiego wyjaśnienia, była emanacyjna metafizyka Plotyna. W systemach XVII-wiecznych ulegała ona różnorodnym modyfikacjom, ale jej główna idea, wskazująca na aktywną rolę pewnych 'zasad', czy 'duchów' odpowiedzialnych za inicjowanie wszelkich zmian w materii i kierowanie nimi zgodnie z zamysłem Stwórcy, pozostawała fundamentem ówczesnych teorii działania materii. Przykładem takich rozwiązań są systemy Henry'ego More’a i jego dobrego znajomego z Cambridge, Izaaka Newtona. W pierwszym przypadku nie ma wątpliwości co do zasadniczego wpływu neoplatonizmu, w drugim jednak zdania historyków są podzielone. Newton sięga bowiem w poszukiwaniu 'aktywnych zasad' do badań alchemicznych, z nadzieją odnalezienia owych zasad nie tylko przy odwołaniu się do filozoficznych spekulacji, ale także do metod eksperymentalnych. Różnica ta jednak nie zmienia faktu, że obaj filozofowie starają się odkryć sposób działania 'duchów aktywnych', wahając się między umieszczeniem w cząstkach materii wielu odrębnych zasad a wskazaniem na zasadę jedną, działającą uniwersalnie i będącą niejako przedłużeniem Bożego ramienia - More nazywa ją Duchem Natury (Vicarious Power of God), a Newton upatruje jej ostatecznie w Chrystusie (Viceroy of God).
\end{abstract}

Słowa kluczowe: materia, ruch, zasady aktywne, Bóg, neoplatonizm, alchemia, Henry More, Izaak Newton

1. Wstęp. 2. Henry More i koncepcja Ducha Natury. 3. Newton i koncepcja 'aktywnych zasad'. 4. Zakończenie. 


\section{WSTĘP}

Nowożytną filozofię naturalną przedstawiano tradycyjnie jako starcie odchodzącego w przeszłość arystotelizmu i jego fizyki jakościowej, z pojawiającymi się nowymi sposobami wyjaśniania działania świata materialnego. Chodziło przede wszystkim o rodząca się fizykę ilościową i związany z nią korpuskularyzm, odwołujący się w wyjaśnianiu szeroko rozumianego działania ciał jedynie do kształtu, wielkości i ruchu cząstek składających się na przedmioty materialne. Rozwój badań nad historią filozofii naturalnej zaowocował jednak w ostatnich dziesięcioleciach znacznym poszerzeniem owego obrazu, okazało się bowiem, że odkryć nowożytnej fizyki dokonano w pejzażu intelektualnym wykraczającym daleko poza wyżej wskazany schemat. Prowadzone przez Newtona badania nad interpretacją Biblii, czy jego długoletnie zainteresowanie alchemią nie były ówcześnie czymś wyjątkowym, czy drugoplanowym w kontekście badań filozoficzno-przyrodniczych. Wynikały z klimatu intelektualnego ówczesnej epoki, której częścią przecież byli twórcy nowożytnej filozofii przyrody. Pytanie o zasady działania materii było ściśle związane z pytaniami natury teologicznej, a odpowiedzi na nie szukano nie tylko w odrodzonej tradycji atomistycznej, nie odrzucano bowiem $\mathrm{z}$ góry rozwiązań zakorzenionych w innych systemach filozoficznych.

Niniejszy artykuł jest próbą zilustrowania istotnego wpływu na nowożytną brytyjską filozofię naturalną jednej z takich tradycji, a mianowicie neoplatonizmu. Wydaje się, że tradycja ta była bardzo żywa przez długi czas, widzimy jej obecność w renesansie, przez cały XVII i do połowy XVIII wieku. Oczywiście niemożliwe jest przedstawienie całego neoplatońskiego kontekstu nowożytnej filozofii naturalnej, ograniczę się więc do jednego tylko zagadnienia - wyjaśnienia zasady działania świata materialnego. Innymi słowy chodziło o odpowiedź na pytanie - co sprawia, że materia w ogóle działa? Dziedzictwo koncepcji 'materii pierwszej' i jej czystej potencjalności 
było wciąż żywe i przyjęcie istnienia korpuskuł, czy atomów niewiele tu zmieniało, dominowało więc przekonanie o całkowitej bierności ciał. Ich działanie domagało się jakiegoś wyjaśnienia, które stanowiłoby odpowiednik arystotelesowskiej, niematerialnej i aktywnej, formy. Trzeba w tym kontekście pokreślić, że neoplatoński światopogląd zakładał ścisłą jedność wszystkich bytów, która znajdowała swój wyraz w jego emanacyjnej metafizyce. W wersji chrześcijańskiej oznaczała ona nieprzerwany łańcuch bytów, który miał swoje źródło w Bogu, a kończył się na materii. Tak więc działanie bytów materialnych mogło zostać wyjaśnione przez odwołanie się do pewnych duchowych zasad działających niejako wewnątrz materii. Wydaje się, że dla wielu nowożytnych filozofów rozwiązanie to było bardzo obiecujące, a poglądy Henry'ego More'a i Isaaca Newtona stanowią dobrą ilustrację wpływu neoplatonizmu na brytyjską filozofię nowożytną.

\section{HENRY MORE I KONCEPCJA DUCHA NATURY}

Zainteresowanie More’a filozofią platońską powiązane było z jego przemyśleniami dotyczącymi zagadnień religijnych. W wieku kilkunastu lat porzucił on bowiem kalwinizm, nie mogąc pogodzić doktryny predestynacji z ideą dobroci Boga, i dołączył do wyznania anglikańskiego. W tym czasie doświadczył też głębokiej duchowej przemiany, na skutek której postanowił cały swój intelektualny wysiłek skierować ku walce z budzącymi się ówcześnie prądami ateistycznymi, co chciał osiągnąć przede wszystkim poprzez wykazanie obecności i działania Boga w świecie. W poszukiwaniu filozofii, z jednej strony najbardziej odpowiedniej dla wyrażenia swych przekonań religijnych, a $z$ drugiej najbardziej przydatnej $w$ walce $\mathrm{z}$ ateizmem, zwrócił się ku platonizmowi. Filozofię te poznał poprzez lekturę Ennead Plotyna, a także dzieł Marcilio Ficino, a jak 
sam wyznał, największe wrażenie wywarła na nim lektura platońsko zabarwionego, mistycznego dzieła Theologia germanica ${ }^{1}$.

Pod koniec lat czterdziestych XVII wieku More zetknął się z filozofią Kartezjusza i wiązał z nią przez jakiś czas pewne nadzieje, ceniąc w niej przede wszystkim istotną rolę przypisywaną substancji duchowej. Wkrótce jednak zdał sobie sprawę, że radykalne rozdzielenie tego, co duchowe i tego, co materialne może, przy odpowiedniej interpretacji kartezjanizmu, doprowadzić do wyeliminowania z obrazu świata tego, co 'nierozciągłe' (a więc nigdzie nieistniejące) i obdarzenia materii 'samowystarczalnością. Stanowiło to w jego przekonaniu jasną zapowiedź możliwości zajęcia stanowiska ateistycznego. Stąd też wzięła się zdecydowana krytyka, jaką More sformułował pod adresem kartezjanizmu. Chodziło przede wszystkim o to, że Kartezjusz przypisywał zbyt dużą skuteczność samej materii, mającej poruszać się jedynie za pomocą zwykłych praw mechanicznych. Gdyby pierwotna materia wszechświata poruszała się tylko „naturalnie”, nie byłoby takiego zróżnicowania, jakie obserwujemy pośród przedmiotów tego świata, ani ziemia, ani woda, ani wiry, ani żadna złożona rzecz nie mogła by się pojawić. More poruszał też kwestię nieadekwatności czysto mechanicznego systemu, w którym sfera materii miała być poddana bezwzględnej konieczności działających praw natury. Materia dla platoników miała najniższy możliwy status ontologiczny i sama nie mogła wykonywać wyższych operacji związanych z widocznym w naturalnym świecie, rozumnym, boskim zamysłem. Dla realizacji takiego projektu konieczne było przyjęcie jakiegoś duchowego pryncypium, kierującego działaniem cząstek materialnych. „Duch natury” lub „dusza świata”, pośrednicząc między Bogiem a materią, miał(-a) pełnić taką kierowniczą rolę i organizować materię zgodnie z boskim planem².

1 Por. R. Ward, The Life Of Henry More, red. S. Hutton, C. Courtney, M. Courtney, R. Crocker, A.R. Hall, Dordrecht 2000, 16-19.

2 B.J.T. Dobbs, The Janus faces of genius. The role of alchemy in Newton's thought, Cambridge 1991, 94; Plotyn wyraża myśl o zależności kolejnych hipostaz w dziele tworzenia ciał następująco: „natura nie jest świadoma, lecz tylko tworzy: daje mianowicie bez żadnego 
Tak więc neoplatońską odpowiedzią na czysto mechaniczne rozumienie Natury była wewnętrzna wobec świata materialnego duchowa zasada, która ostatecznie miała być odpowiedzialna za wszelkiego rodzaju działanie zachodzące w świecie naturalnym. H. More nazwał tę zasadę Duchem Natury (Spirit of Nature), który stanowił część emanacyjnego systemu metafizycznego. Zgodnie z obowiązującą w nim zasadą oddziaływania na siebie poszczególnych hipostaz, to Dusza odpowiada za proces formowania materii. Duch Natury spełniał w tym procesie rolę zasady, która nadaje materii cechy określone przez Boga. Ponieważ Duch Natury jest skierowany ku materii, a świat materialny jest odwrotnością natury Boga, More daje mu najniższą rangę w przejawieniu się ducha w materii. Duch Natury nie ma żadnych władz poznawczych, jakimi obdarzone są dusze indywidualne, dlatego też Duch Natury pozbawiony jest świadomości ${ }^{3}$.

More modyfikował koncepcję Ducha Natury w kolejnych dziełach, wahając się między ideą Natury rozumianej jako wielość indywidualnych duchowych zasad, mających działać np. w poszczególnych roślinach, a ideą jednego tylko, działającego we wszystkich bytach materialnych Ducha Natury ${ }^{4}$. Najbardziej dojrzałą formę koncepcja Ducha Natury osiagga w dziele z 1659 r. The Immortality of the Soul, w którym odnajdujemy następujące jego określenie: „niecielesna substancja pozbawiona zmysłów i umysłu (animadversion), przenikająca całą materię wszechświata i posiadająca wegetatywną (plastic) władzę jej kształtowania zgodnie z licznymi predyspozycjami

zamiaru ze swej strony temu, co następuje z kolei, to, co posiada, i owo dawanie temu, co cielesne i materialne, stanowi właściwe jej tworzenie (...), bo ową postać, jaką natura nadaje ukształtowanemu ciału, należy uważać za 'ideę różną od samej natury..., natura, tworząca w materii, tworzy i doznaje, ta dusza, która jest przed nią i blisko niej, tworzy, ale nie doznaje, a dusza jeszcze wyżej nie tworzy ani w ciałach, ani w materii", Plotyn, Enneady, t.II, tłum. z gr. A. Krokiewicz, Kraków 1959, IV, 4, 13, 80-81.

3 H. More, Notes upon 'Psychozoia', c. 1, st. 41 w: The Complete Poems, red. A.B. Grosart, Edinburgh 1878, 139b.

4 Por. J. Reid, The Metaphysics of Henry More, Dordrecht - Heidelberg - New York - London 2012, ch. 9. 
i sposobnościami [znajdującymi się] w częściach [materii], nad którymi pracuje. Wzbudza ona w świecie takie zjawiska, kierując częściami materii i ich ruchem, których nie można by sprowadzić do zasad czysto mechanicznych"5.

Duch Natury pełni w filozofii More'a niezwykle istotną rolę w wyjaśnieniu relacji Boga do materii, a dokładniej w wyjaśnieniu oddziaływania Boga na świat materialny. W tym kontekście Duch Natury odpowiedzialny jest za wszystkie działania materii, które nazywamy witalnymi, a wszelki ruch materii przez Niego powodowany jest swego rodzaju dynamicznym odbiciem porządku, wyznaczanego w bezkształtnej materii przez umysł Boski. More podkreśla jednak, że Duch Natury działa nieświadomie, jego władze można zakwalifikować jedynie jako wegetatywne i zmysłowe, jest on całkowicie niezdolny do wykonywania działań umysłowych. Ujawniają się tu oczywiście wpływy neoplatońskie, Umysł Boży musi pozostawać całkowicie oddzielony od świata materialnego, a Duch Natury „zawiera witalnie w każdym swoim punkcie wszystkie cielesne (mundane) formy, wraz ze wszystkimi poszczególnymi częściami każdej z nich (ponieważ wszechforma życia <omniform Life> Ducha Natury, na ile odnosi się do świata, odpowiada wszechformie samego boskiego Intelektu)"6.

Tak więc działanie Ducha Natury w świecie materialnym można określić jako działanie kierowane instynktem, czy też postępowanie nieświadome, ale zawsze zgodne $\mathrm{z}$ formami i prawami określonymi ostatecznie przez Boga. Ponadto, w ujęciu More'a, jest on jedynym czynnikiem działającym na poziomie wegetatywnym we wszystkich

5 H. More, Immortality of the Soul bk. 3, ch. 12 § 1, red. A. Jacob, Dordrecht 1987, 254; jeśli nie podano inaczej, tłumaczenia tekstów własne autora artykułu.

$6 \mathrm{H}$. More, Immortality of the Soul, 'Notes' on Book II, ch. 12, § 12 w: H. More, A Collection of Several Philosophical Writings, London 1712, 119, wydanie A Collection of Several Philosophical Writings z 1712 r. uzupełnione jest przez komentarze i scholia, których brak w wydaniach wcześniejszych, nie ma ich również w wydaniu The Immortality of the Soul edytowanym przez A. Jacoba. 
bez wyjątku istotach żywych. Rozwiązanie to zgodne jest z klasyczną zasadą Frustra fit per plura quod fieri potest per pauciora („na próżno czyni się za pomocą wielu [przyczyn] to, co można uczynić za pomocą niewielu"), bo logiczne jest, by funkcje życiowe wszystkich np. roślin kierowane były przez jednego 'wegetatywnego' ducha. Taka jedność działania najlepiej wyjaśnia ich ,przemiany gatunkowe, wzrost młodych pędów (slips) itd. Bo jest tylko jedna Dusza gotowa działać wszędzie dla korzyści przygotowanej [wcześniej przez Boga] materii. Jest ona wspólnym i jedynym logos spermatites wszystkich form roślinnych". Zwierzęta i ludzie są dodatkowo obdarzeni duszami indywidualnymi, co pozwala im cieszyć się doznaniami zmysłowymi

\section{NEWTON I KONCEPCJA 'AKTYWNYCH ZASAD'}

Henry More był członkiem Christ's College w Cambridge, zarazem właśnie w Cambridge Isaac Newton spędził dużą część swojego życia. Newton i More wykładali wspólnie na Uniwersytecie w Cambridge przez ponad 25 lat, a ich znajomość mogła trwać dłużej, gdyż Newton dorastał w Grantham, rodzinnym mieście More’a i uczęszczał do tej samej szkoły co wcześniej More. Bliski kontakt między nimi może być potwierdzony faktem, że More zapisał Newtonowi w swoim testamencie pierścień pogrzebowy, wymieniając go z imienia obok czternastu innych osób. Ich bliska znajomość nie jest jednak okolicznością szczęśliwą z naukowego punktu widzenia, ponieważ musieli oni mieć wiele okazji do bezpośrednich spotkań, a zarazem dyskusji o wielu zagadnieniach filozoficznych. W rezultacie nie dysponujemy żadną korespondencją między nimi i możemy jedynie spekulować na temat wzajemnych wpływów filozofii More’a i Newtona. Wiemy

7 Por. A. Jacob, The Neoplatonic Conception of Nature in More, Cudworth, and Berkeley w: The Uses of Antiquity. The Scientific Revolution and the Classical Tradition, ed. S. Gaukroger, Dordrecht 1991, 108-109, cytat: H. More, Immortality of the Soul bk. 3, ch. 13 §7, red. A. Jacob, dz. cyt., 262-263. 
jednak, że w swej bibliotece Newton miał kilka dzieł More'a, a niektóre $z$ nich były osobistymi prezentami od autora ${ }^{8}$. Wszystko to razem pozwala przypuszczać, że przynajmniej niektóre pomysły More'a wpłynęły na filozofię Newtona. To przypuszczenie jest szczególnie prawdopodobne w przypadku zagadnienia funkcjonowania świata materialnego.

Przed 1666 r. Newton skupiał się na tym, co naukowcy nazywają makrokosmosem lub samym kosmosem. Po 1666 r. jego zainteresowania poszerzyły się o mikrokosmos, czyli najmniejsze cząstki niewidzialnej materii, przez które wszystkie rzeczy w naturze powstają, rosną, rozpadają się i ostatecznie wracają do swoich podstawowych elementów. Studiując ten świat, Newton wierzył, że może odkryć czym jest naprawdę światło, jak siły takie jak grawitacja i magnetyzm działają na duże odległości i jak eter wywołuje zmiany w ciałach, w których się znajduje9.

Poglądy Newtona dotyczące zasady działania przedmiotów materialnych ewoluowały przez dziesięciolecia prowadzonych przez niego poszukiwań, dlatego też niełatwo jest wskazać jednoznacznie na przyjęte przez niego szczegółowe rozwiązania. Historycy filozofii różnią się np. co do roli, jaką należy przypisać koncepcji eteru, konsekwentnie przywoływanej przez Newtona dla wyjaśnienia zjawisk zachodzących w świecie materialnym (m.in. fermentacja, gnicie itp.), czy do interpretacji takich pojęć, jak 'siła', czy 'zasada aktywna', które stanowią istotną część jego teorii1 ${ }^{10}$. Wydaje się, że jedną z przyczyn kontrowersji może być dwuznaczność, z jaką Newton posługuje

8 Wiemy na pewno, że Newton czytał The Immortality of the Soul More'a. Wspomina o tym w swych niepublikowanych 'Zapiskach' - "It remaines therefore yt ye first matter must be attoms And yt Matter may be so small as to be indiscerpible the excellent Dr. Moore in his booke of ye soules imortality hath proved beyond all controversie", por. A. R. Hall, Sir Isaac Newton's Note-Book, 1661-65, Cambridge Historical Journal 9(1948)2, 243.

9 Por. G. Christianson, Isaac Newton, Oxford - New York 2005, 57.

10 Por. np. poglądy A.R. Hall, M. Boas Hall, Unpublished Scientific Papers of Isaac Newton. A Selection from the Portsmouth Collection in The University Library, Cambridge, red. i tłum. A.R. Hall, M. Boas Hall, Cambridge - London - New York - Melbourne 1978, 183-213 
się tymi i innymi pojęciami (np. elastic spirit, vital principle), pewne teksty zdają się bowiem wskazywać, że umieszcza te 'przedmioty' po stronie świata materialnego, a inne, że po stronie świata duchowego ${ }^{11}$. Nie należy też zapominać, że Newton był człowiekiem swojej epoki, co w tym przypadku oznacza, że jego poglądy kształtowały się pod wpływem dominującego ówcześnie obrazu świata - stworzonego i kierowanego w swych działaniach przez Boga. Obecność Stwórcy w przyrodzie musiała się więc w jakiś sposób zaznaczać, a co za tym idzie przyjmowana koncepcja materii musiała ten stan odzwierciedlać. W rezultacie u Newtona koncepcja ta była wypadkową rozwiązywanych problemów z zakresu mechaniki, matematyki i metafizyki ${ }^{12}$. Co do możliwości działania samej, rozumianej atomistycznie, materii Newton zajmuje jednak stanowisko powszechnie wtedy przyjmowane - jest ona całkowicie pasywna, jeśli działa, to jedynie pod wpływem jakiegoś aktywnego czynnika ${ }^{13}$.

Istotną rolę $\mathrm{w}$ kształtowaniu poglądu na zasadę działania materii odegrały poglądy religijne Newtona. Kierując się podobnymi co

z poglądami: I.B. Cohen, Issac Newton's Papers and Letters on Natural Philosophy and related documents, red. I.B. Cohen, Cambridge, Massachusetts 1958, 4-9.

11 Por. np. I. Newton, Quaery 1: Do not bodies act upon light at a distance, and by their action bend its rays (...) ?, Quaery 19: Doth not the refraction of light proceed from the different density of [the] aetherial medium in different places, the light receding always from the denser parts of the medium?, Quaery 31: Have not the small particles of bodies certain powers, virtues, or forces by which they act at a distance, not only on the rays of light (...) but also upon one another for producing a great part of the phenomena of nature?; I scruple not to propose the Principles of Motion above-mention'd, they being of very general Extent, and leave their Causes to be found out" w: Opticks: or, A Treatise of the Reflections, Refractions, Inflections and Colours of Light, London 1730, 339, 349, 375-376, 402.

12 Por. E. McMullin, Newton on Matter and Activity, Notre Dame - London 1978, 106-109.

13 Pogląd ten wyrażony jest najdobitniej w często przywoływanym w literaturze Liście do Bentleya: "It is inconceivable, that inanimate brute Matter should, without the Mediation of something else, which is not material, operate upon, and affect other Matter, without mutual contact", Letter III w: Issac Newton's Papers and Letters on Natural Philosophy, dz. cyt., 302. 
Platonicy z Cambridge obawami dotyczącymi rodzącego się ateizmu, Newton przyjął ich program dowodzenia bożego działania w świecie. Celem nie było dlań jednak odrzucenie filozofii mechanicznej jako takiej, ale zmodyfikowanie jej poprzez dodanie do jej schematu zasad duchowych zdolnych do inicjowania ruchu, a w konsekwencji wszelkich zmian w całkowicie biernej materii. Zasady te miały następnie kierować materią, formując ją w zaprojektowane przez Boga konfiguracje. Niektórzy historycy filozofii twierdzą, że wpływ samej filozofii neoplatońskiej dostarcza odpowiedniego wyjaśnienia dla odwoływania się przez Newtona w jego filozofii naturalnej do aktywnych, duchowych zasad ${ }^{14}$. Inni twierdzą jednak, że nie zadowalał się on argumentacją filozoficzną i dlatego zaczął studiować alchemię. Alchemicy bowiem nie tylko odwoływali się do duchowych, aktywnych zasad w wyjaśnianiu zmian w materii, ale ponadto twierdzili, że mogą dostarczyć eksperymentalnych dowodów na ich działanie ${ }^{15}$.

Niezależnie od tego czy decydujący wpływ na Newtona miała jedynie filozofia neoplatońska, czy też należy taki wpływ przypisać traktatom alchemicznym, to znaczenie neoplatonizmu w tym kontekście pozostaje bardzo istotne. Trzeba bowiem podkreślić, że

14 Por. J.E. McGuire, Neoplatonism and active principles: Newton and the 'Corpus Hermeticum' w: Hermeticism and the Scientific Revolution: Papers Read at a Clark Library Seminar, March 9, 1974, ed. R.S. Westman, J.E. McGuire, Los Angeles 1977, 93-142.

15 B.J.T. Dobbs, The Janus faces of genius, dz. cyt., 94-95. W ostatnich dziesięcioleciach podjęto intensywne badania dotyczące istoty badań alchemicznych i ich roli w rozwoju filozofii naturalnej i ostatecznie w powstaniu nowożytnej nauki. Literatura poświęcona temu zagadnieniu jest niezwykle obszerna, por. np. B.T. Moran, Distilling Knowledge. Alchemy, Chemistry and the Scientific Revolution, Cambridge, Massachusetts 2005; W. Newman, Alchemical Atoms or Artisan "Building Blocks"? A Response to Klein, Perspectives on Science 17(2009)2, 212-229; L. M. Principe, Alchemy Restored, Isis 102(2011)2, 305-312, który podkreśla fakt, że alchemia była przede wszystkim częścią nowożytnej filozofii naturalnej (a nie jedynie swoistym przygotowaniem dla powstania naukowej chemii) , w której 'natura' rozumiana była jako ‘kosmos' złożony z Boga-Stwórcy, człowieka i przyrody. 'Kosmos' ten miał swój sens, cel i był wypełniony różnorodnymi symbolami, które czekały na odszyfrowanie. Filozofia naturalna musiała zatem być mieszaniną nauki, teologii i metafizyki, 311. 
choć alchemia była zjawiskiem niezmiernie złożonym, to tradycja platońska stanowiła niezaprzeczalnie jeden z głównych filarów samej alchemii ${ }^{16}$.

Wydaje się, że do stanowisk stojących u fundamentu badań alchemicznych można zaliczyć witalizm ${ }^{17}$, zgodnie $\mathrm{z}$ którym cały kosmos interpretowany jest jako organizm ożywiany przez jedną lub więcej zasad duchowych. Zasady te miały być odpowiedzialne za wszystkie zmiany w świecie przyrody. I tak np. w ujęciu witalistycznym metale nie były traktowane jak osobne gatunki, ale widziano w nich raczej coś w rodzaju współczesnych stopów metali, obdarzanych różnego rodzaju, zmieniającymi się właściwościami. Metale można było traktować jak swego rodzaju ciasto, w którym dodanie pewnych aktywnych składników powodowało, podobnie jak zakwas w cieście, określone zmiany na kształt procesu podobnego do fermentacji, metale były więc postrzegane jako rodzaj nie do końca uformowanej materii, do której można dodać jakąś postać aktywnego składnika i tak doprowadzić do procesu powstawania nowych cech. Przez analogię alchemicy nazywali tę zasadniczą fazę swych eksperymentów laboratoryjnych fermentacją lub wytwarzaniem (generation), a uzyskanie odpowiedniego dla konkretnych zamierzeń ożywiającego (vital) zaczynu lub nasienia stało się podstawową częścią ich poszukiwań. Podobne idee pojawiają się u Arystotelesa i są powszechne w czasach Newtona ${ }^{18}$.

W swoich późniejszych pismach Newton zajął stanowisko, zgodnie z którym działanie czysto mechaniczne nigdy nie może wyjaśnić wielu procesów istotnych nie tylko dla zjawiska życia, ale także dla obserwowanego zróżnicowania rzeczy. Taki mechanizm nie mógł wyjaśnić np. procesu asymilacji, w którym żywność zostawała

16 Por. np. H. Hirai, The World-Spirit and Quintessence in the Chymical Philosophy of Joseph Du Chesne w: Chymia: Science and Nature in Medieval and Early Modern Europe, red. M. López Pérez, D. Kahn, M. Rey Bueno, Newcastle 2010, 247-261.

17 Por. np. K. Chang, Alchemy as Studies of Life and Matter: Reconsidering of Place of Vitalism in Early Modern Chymistry, Isis 102(2011)2, 322-329.

18 B.J.T. Dobbs, Newton's Alchemy and His Theory of Matter, Isis 73(1982)4, 515. 
zamieniona w ciała zwierząt, warzyw i minerałów, ani też nie mógł stanowić wyjaśnienia faktu różnorodności form w świecie, z których wszystkie musiały w jakiś sposób wyłonić się ze wspólnej wszystkim materii. Jak Newton miał wreszcie powiedzieć w Scholium Ogólnym do Principiów: „Żadna różnorodność rzeczy nie może wyniknąć ze ślepej konieczności metafizycznej [tj. działania mechanicznego], która zawsze i wszędzie mus być taka sama”. W końcu to Bóg jest odpowiedzialny za świat przyrody, Ten, który stworzył świat, użył swojej mądrości i opatrzności, aby stworzyć „całą tę różnorodność rzeczy naturalnych, każdą w swoim czasie i miejscu"19. Jednak Bóg był przyczyną ostateczną, a Newton chciał znaleźć w świecie przyrody przyczyny, które miały bezpośrednio wywoływać zjawiska związane z procesami życiowymi, mające być czynnikiem działającym w tych sprawach z polecenia Boga ${ }^{20}$.

W XVII wieku przekonanie o panowaniu Boga-Stwórcy nad światem było powszechnie akceptowane, ale filozofowie różnili się w poglądach co do tego, w jaki sposób władza Boga nad światem realizowana jest w przypadku przedmiotów materialnych. Choć Kartezjusz twierdził, że Bóg nieustannie i aktywnie działa we wszechświecie, podtrzymując go w istnieniu swoją wolą, to wielu filozofów zgłaszało do jego koncepcji poważne zastrzeżenia. Chodziło głównie o to, że Bóg Kartezjusza zbyt łatwo może być potraktowany jak odległy od swego stworzenia Stwórca, który co prawda wprawił na początku materię w ruch, ale którego rola w kierowaniu działaniem materii była niejasna, a w konsekwencji mogła się stać po prostu zbędna. Newton, podobnie jak wszyscy inni, musiał zmierzyć się $\mathrm{z}$ tą teologiczną trudnością. I w tym właśnie miejscu zaznacza się w poglądach Newtona wpływ filozofii neoplatońskiej, odwołuje się on bowiem do koncepcji, pośredniczących między Bogiem a materią,

19 Obydwa cytaty: I. Newton, Matematyczne zasady filozofii przyrody, tłum. z ang. J. Wawrzycki, Kraków 2011, Scholium ogólne, 693.

20 B.J.T. Dobbs, Newton's Alchemy, dz. cyt., 515-516. 
'aktywnych zasad', których zadaniem jest wprawianie przyrody w ruch, tzn. wywoływanie i kierowanie wszelkimi zachodzącymi w niej zmianami. Przez dziesięciolecia Newton poszukiwał odpowiedzi na pytanie o istotę działania tych 'aktywnych zasad', dostrzegając różnice zachodzące między konkretnymi zmianami w świecie (np. między grawitacją, fermentacją i zjawiskami elektrycznymi). W tym kontekście pojawiają się takie pojęcia jak 'siła', 'aktywny eter', 'duch elektryczny', czy 'ożywiająca zasada', odpowiadają one badanym przez Newtona zmianom w przyrodzie. Wydaje się jednak, że wyróżnionym przez niego w tym kontekście rodzajem zjawisk naturalnych były te związane z badaniami alchemicznymi. Nieprzypadkowo poświecił tej dziedzinie kilkadziesiąt lat swego życia. To właśnie tam usilnie szukał odpowiedzi na pytanie o działanie materii ${ }^{21}$.

Odpowiedzią Newtona na wskazane powyżej trudności natury teologicznej miała być właśnie owa, postulowana przez alchemików, substancja czynna, duch ożywiający (vital spirit). To za jego pośrednictwem Bóg sprawował swoją opatrznościową władzę nad światem materii, wprawiając w ruch jej cząstki i kierując wszystkimi ich działaniami. Co więcej, taki działający w naturze 'czynnik' (agent) nie stanowił, zdaniem Newtona, zagrożenia dla pojęcia wszechmocy Boga, przeciwnie, mógł wzmacniać przekonanie o mocy Bożej: ,jeśli ktoś pomyśli, iż byłoby możliwe, aby Bóg stworzył jakąś istotę rozumną na tyle doskonałą, że mogłaby ona za Jego zgodą tworzyć istoty niższe, to zamiast umniejszać Bożą moc, powiększyłoby to ją; albowiem moc, która może stworzyć istoty nie tylko w sposób bezpośredni, ale także za pośrednictwem innych istot jest znacznie, jeśli nie nieskończenie większa”22.

21 Klasyczną pozycją poświęconą roli alchemii w poglądach Newtona jest: B.J.T. Dobbs, The Janus faces of genius. The role of alchemy in Newton's thought, Cambridge 1991.

22 I. Newton, O ciężkości i równowadze cieczy, w: Empiryczne podstawy i obrzeża filozofii XVII wieku, red. B. Grabowska, A. Grzeliński, J. Żelazna, tłum. z ang. A. Grzeliński, Toruń 2014, 221-222. 
W traktacie Ofnature's obvious laws and processes in vegetation Newton stosuje termin 'wegetacja' w bardzo szerokim zakresie. Ma ona zachodzić na wszystkich trzech poziomach świata naturalnego - mineralnym, zwierzęcym i roślinnym, i na wszystkich trzech kierowana jest przez aktywną zasadę nazywaną 'duchem roślinnym' (vegetable spirit) ${ }^{23}$. Pogląd Newtona na temat owego 'ducha roślinnego' ewoluował. Początkowo utożsamiał go z przenikającym wszystkie rzeczy eterem, który wpleciony w grubszą teksturę postrzeganej zmysłowo materii, stanowić miał materialną duszę wszystkich rzeczy. Jest to ten sam materialny eter, który jest nieustannie kierowany przez wegetatywną duszą świata i którego aktywność wyjaśnia również działanie grawitacji. W późniejszym okresie Newton zmienił jednak zdanie, by powiedzieć, że eter jest prawdopodobnie tylko rodzajem nośnika dla ,jakiegoś bardziej aktywnego ducha”, działającego poprzez eter i w nim. Zaznacza się tu wyraźny wpływ neoplatonizmu, ponieważ ten 'aktywny duch' zostaje porównany przez New tona do światła ${ }^{24}$, a dokładniej może stanowić on „ciało światła” (the body of light). Niektóre analogie i związki między 'duchem roślinnym' a światłem mogą być wskazane w następujący sposób: „Ten duch jest być może ciałem światła, ponieważ obaj mają tę zdumiewającą aktywną zasadę, obaj są wiecznymi pracownikami. 2 Ponieważ, poprzez ciepło, wszystkie rzeczy moga emitować światło. 3 Ta sama przyczyna (ciepło) eliminuje także zasadę życiową (vital principle). 4 Zgodne z nieskończoną mądrością jest to, by nie mnożyć przyczyn bez konieczności. 5 Żadne ciepło nie jest tak przyjemne i jasne jak to słoneczne. 6 Światło i ciepło

23 I. Newton, Of nature's obvious laws and processes in vegetation, nr 6, http://webapp1. dlib.indiana.edu/newton/mss/norm/ALCH00081/query/field1=text1=of\%20natures\%20 obvious\%20laws [dostęp 18.07.2018].

24 Światło stanowiło istotną część metafizyki neoplatoników, którzy przypisywali mu cechy bardziej duchowe, niż materialne. Cała rzeczywistość, od Boga po materię, mogła być światłem rozpościerającym się na ogromnej skali - od olśniewającego blasku Boga do mroków materii, por. S. Swieżawski, Dzieje filozofii europejskiej XV wieku, t. 3, Warszawa 1978, 206-207. 
są od siebie wzajemnie zależne, a żadne powstawanie (generation) [nie odbywa się] bez ciepła. Ciepło jest warunkiem koniecznym dla światła i wegetacji. [Ciepło wzbudza światło, a światło wzbudza ciepło; ciepło wzbudza zasadę roślinną (vegetable), a ta powiększa ciepło]. Żadna substancja tak obojętnie, subtelnie i szybko nie przenika wszystkich rzeczy jak światło, a żaden duch nie przemierza ciał tak subtelnie, przenikliwie i szybko jak duch roślinny"25.

W wielu alchemicznych traktach znajdujemy termin „iluminacja”, który wskazuje na pewien model działań Boga na początku czasu, działań mających miejsce na poziomie mikro-kosmosu. Przenikające wszystkie stworzenia światło miało być Bożym posłańcem, niosącym wszędzie ożywiającego materię 'ducha roślinnego' (vegetare - ożywiać). Było to oczywiście związane z opisem stworzenia w Księdze Rodzaju, ale tę substancję czynną można było również utożsamić z duchem Bożym, który 'poruszał się ponad wodami' i rzeczywiście czasami była ona z nim utożsamiana. Wprowadzało to więc pewną dwuznaczność co do charakteru 'aktywnej zasady', odpowiedzialnej za wprawienie materii w ruch i kierowanie nim. Wydaje się, że 'duchy', czy 'zasady' filozofów XVII wieku zamieszkiwały swoistą szarą strefę między tym, co cielesne i tym, co niematerialne, przesuwając się w jedną lub drugą stronę, w zależności od tego, jaki problem próbowano przy ich użyciu wyjaśnić.

Nawet jeśli w pracach Newtona znajdziemy wiele śladów jego wahania się co do natury 'duchów' i 'sił' inicjujących określone zmiany $\mathrm{w}$ świecie materialnym, od grawitacji do gnicia i wegetacji, to nie zmienił on swego zasadniczego stanowiska. Jego zdaniem aktywne siły odpowiedzialne za działanie świata naturalnego nie mogły być wewnętrznymi, wrodzonymi cechami materii. Inicjowanie działania i kierowanie nim było wyłączną domeną Boga, przypisanie „bezmyślnej materii” zdolności generowania ruchu otwierałoby

25 Por. B.J.T. Dobbs, Newton's Alchemy, dz. cyt., 520-521, cytat: I. Newton, Burndy MS: fol. 4r, za B.J.T. Dobbs. 
bowiem drogę dla ateizmu. Newton zawsze był świadom ryzyka związanego z przypisywaniem aktywności materii i zawsze nalegał, by jego 'siły' działały tylko między cząstkami. W rzeczywistości nie były one częścią samej materii, lecz były przejawami działania Boga w naturze. Następcy Newtona wkrótce odrzucili ten sposób rozumienia sił kierujących działaniem materii, jednak sam Newton, określając siły jako czynniki aktywne, oddziałujące na przedmioty materialne, rozumiał je jako przejaw jedynego zdolnego do rzeczywistego działania (w sensie metafizycznym) Boskiego ducha. Choć wypowiedzi Newtona oscylują między uznaniem bezpośredniego lub pośredniego oddziaływania Boga na przyrodę, to owe "boskie duchy', pomimo dwuznaczności XVII-wiecznego użycia terminu 'duch' są jednoznacznie niematerialne: „On [Bóg] jest wszechobecny, nie tylko przez moc [per virtutem], lecz również substancjalnie. Moc bowiem nie może się utrzymywać bez substancji”, „(...) ci starożytni, jak Tales i Stoicy, którzy bardziej właściwie utrzymywali tę mistyczną filozofię nienaruszoną, nauczali, że pewien nieskończony duch przenika całą przestrzeń w nieskończoność, zawiera [w sobie] i ożywia cały świat" 26 .

Działanie Boga w świecie to zagadnienie nie tylko filozoficzne, ale przede wszystkim teologiczne. Stąd też i w poglądach Newtona pojawia się tego rodzaju refleksja. Jak wiemy zajmował się on teologią nie mniej niż filozofią naturalną i do badań z tej dziedziny przywiązywał olbrzymią wagę ${ }^{27}$. W kontekście obecnych rozważań istotne jest to, że prowadzona przez lata egzegeza Pisma Świętego skłoniła Newtona do przyjęcia stanowiska antytrynitarnego, zgodnie z którym nie można uznać Jezusa Chrystusa za Boga. Określenie

26 Por. B.J.T. Dobbs, Newton's Alchemy, dz. cyt., 526, cytaty: I. Newton, Matematyczne zasady filozofii przyrody, dz. cyt., Scholium ogólne, 692-693; I. Newton, manuskrypt U.L.C MS Add. 3965.12, cyt. za: J.E. McGuire and P.M. Rattansi, Newton and the 'Pipes of Pan', Notes and Records of the Royal Society of London 21(1966), 119.

27 Por. np. Newton and Religion. Context, Nature and Influence, red. J.E. Force, R.H. Popkin, Dordrecht 1999. 
'Syn Boży' wskazuje na wyróżniony w godności i potędze, ale jednak tylko stworzony byt ${ }^{28}$. Syn Boży ma do spełnienia istotną rolę w dziele stworzenia świata. To właśnie Chrystus, zjednoczony z Bogiem w ,jedności Władzy”, choć nie jedności substancji, sprawił, że owe Boskie zamysły (w oryginale idee) znalazły swą realizację $\mathrm{w}$ świecie przyrody, tworząc całe bogactwo bytów. Przypisanie Chrystusowi tak zasadniczej roli w procesie stwarzania świata i kierowania nim oznaczało, że wszelkie działania przyrody, zarówno te w skali makro-, jak i mikrokosmosu znajdowały się w całkowitej zależności od Syna Bożego. Wszelkie odkrywanie zasad działania natury, niezależnie od tego czy prowadziło do wskazania na 'siły' działające między cząsteczkami materii, na 'eter' mający przenosić ruch w przyrodzie, czy też na 'ducha roślinnego' kierującego nie-mechanicznymi procesami chemicznymi, musiało ostatecznie prowadzić do wniosku, że wszystkie te 'aktywne' zasady muszą być podporządkowane duchowi Bożemu. Pytanie o ich charakter materialny, czy niematerialny schodziło w tej sytuacji na dalszy plan. B. Dobbs podsumowała stanowisko Newtona na temat zasad działania świata materialnego w następujący sposób: „Czy nazywa się je siłami, mocami, mediami, zasadami, czy duchami, i czy działają one na sposób materialny, czy niematerialny - wszystko to jest ostatecznie drugorzędne, bo działanie wymaga [zaangażowania] tego, co boskie, a działanie niemechaniczne wskazuje na obecność tego, co boskie w porządku naturalnym. Działająca w całym wszechświecie (universal) grawitacja dowodzi wszechobecności Boga Ojca; działania wegetatywne (vegetable) w najmniejszych cząstkach

28 "God \& his son cannot be called one God upon account of their being consubstantial," but that they may be called one God through a "unity of Dominion, (...) the Son receiving all things from the Father, being subject to him, executing his will, (...) \& so is but one God with the Father as a king \& his viceroy are but one king." I. Newton, Yahuda 15, cyt. za B.J.T. Dobbs, Newton's Alchemy, dz. cyt., 527. O arianizmie Newtona por. R.S. Westfall, Never at Rest: A Biography of Isaac Newton, Cambridge - London - New York 1980, $311-319$. 
materii (micromatter) wskazują na nieustanne kierowanie światem przez wicekróla Boga, Chrystusa. I tak być może Newton powiedział wreszcie wystarczająco dużo, abyśmy mogli zrozumieć jego intencje, i mogli zakończyć tym ostatnim triumfalnym okrzykiem, którym podsumował on, zarówno dla siebie samego, jak i dla swoich odbiorców dzieło swego życia: »Tyle na temat Boga, refleksja nad Bogiem wychodząca od analizy zjawisk z cała pewnością jest częścią filozofii przyrody«"29.

\section{ZAKOŃCZENIE}

Wątek neoplatoński w dziejach brytyjskiej nowożytnej filozofii naturalnej nie cieszył się dużym zainteresowaniem historyków filozofii aż do drugiej połowy ubiegłego wieku. Nie mieścił się w standardowym obrazie zmagań filozofów nowożytnych, mających promować jedynie atomizm i mechanicyzm, ze zwolennikami scholastyki. Jednak ostatnie dziesięciolecia przyniosły tu radykalną zmianę. Klasyczne ujęcia nowożytności zostały uzupełnione badaniami nad szeroką gamą zagadnień zarówno filozoficznych, jak i teologicznych, by wskazać jedynie na wciąż żywe w XVII wieku prądy renesansowe (właśnie neoplatonizm, hermetyzm i związana $z$ nimi alchemia), czy millenaryzm i związany z nim rozwój egzegezy biblijnej. Dzięki temu dużo lepiej rozumiemy bogactwo intelektualnego pejzażu XVII-wiecznej Wielkiej Brytanii.

Przedstawione powyżej poglądy Henry'ego More'a i Isaaca Newtona dotyczące zasad kierujących zmianami w świecie materialnym zdradzają niewątpliwie wiele podobieństw, opierają się bowiem na tym samym założeniu - materia jest całkowicie bierna i dlatego musi być wprawiana w ruch i kierowana niejako z zewnątrz. Obaj filozofowie przyjmują, że ostatecznie to Bóg-Stwórca jest przyczyną

29 B.J.T. Dobbs, Newton's Alchemy, dz. cyt., 526, cytaty: I. Newton, Matematyczne zasady filozofii przyrody, dz. cyt., Scholium ogólne, 693. 
wszelkich zmian w świecie, jednak obaj przyjmują również, że działa On przy wykorzystaniu swego rodzaju pośredników, 'aktywnych zasad' wykonujących posłusznie Jego polecenia. Oczywiście zachodzą i różnice w poglądach More’a i Newtona. Pierwszy ogranicza się do rozważań o naturze spekulatywnej, przyjmując ostatecznie, że to jeden i niepodzielny Duch Natury kieruje przyrodą. Drugi z nich sięga w poszukiwaniu 'aktywnych zasad' do badań alchemicznych, z nadzieją odnalezienia owych zasad nie tylko przy odwołaniu się do filozoficznych spekulacji, ale także do metod eksperymentalnych. Jak widzieliśmy, obaj filozofowie starają się odkryć sposób działania 'duchów aktywnych', wahając się między umieszczeniem w cząstkach materii wielu odrębnych zasad a wskazaniem na zasadę jedną, działającą uniwersalnie i będącą niejako przedłużeniem Bożego ramienia - More nazywa ją Duchem Natury (Vicarious Power of God), a Newton wskazuje ostatecznie na Chrystusa (Viceroy of God). Poglądy obydwu filozofów ewoluowały, dlatego też podlegają, bywa że konkurencyjnym interpretacjom, jednak wydaje się, że niezależnie od zmieniających się szczegółów fundament ich poglądów na działanie materii jest niezmienny i ten sam - emanacyjna metafizyka Plotyna.

\section{Bibliografia}

Chang K., Alchemy as Studies of Life and Matter: Reconsidering of Place of Vitalism in Early Modern Chymistry, Isis 102(2011)2, 322-329.

Christianson G., Isaac Newton, Oxford University Press, Oxford - New York 2005.

Dobbs B.J.T., Newton's Alchemy and His Theory of Matter, Isis 73(1982)4, 511-528.

Dobbs B.J.T., The Janus faces of genius. The role of alchemy in Nerwton's thought, Cambridge University Press, Cambridge 1991.

Hall A.R., Sir Isaac Newton's Note-Book, 1661-65, Cambridge Historical Journal 9(1948)2, 239-250.

Hirai H., The World-Spirit and Quintessence in the Chymical Philosophy ofJoseph Du Chesne, w: Chymia: Science and Nature in Medieval and Early Modern Europe, red. M. López Pérez, D. Kahn, M. Rey Bueno, Cambridge Scholars Publishing, Newcastle 2010, 247-261. 
Jacob A., The Neoplatonic Conception of Nature in More, Cudworth, and Berkeley, w: The Uses of Antiquity. The Scientific Revolution and the Classical Tradition, red. S. Gaukroger, Springer Science+Buisness Media, Dordrecht 1991, 101-122. McGuire J.E., Neoplatonism and active principles: Newton and the 'Corpus Hermeticum', w: Hermeticism and the Scientific Revolution: Papers Read at a Clark Library Seminar, March 9, 1974, red. R.S. Westman, J.E. McGuire, Clark Memorial Library, University of California, Los Angeles 1977, 93-142.

McGuire J.E., Rattansi P.M., Newton and the 'Pipes of Pan', Notes and Records of the Royal Society of London 21(1966), 108-143.

McMullin E., Newton on Matter and Activity, University of Notre Dame Press, Notre Dame - London 1978.

Moran T., Distilling Knowledge. Alchemy, Chemistry and the Scientific Revolution, Harvard University Press, Cambridge, Massachusetts 2005.

More H., The Complete Poems, ed. A. B. Grosart, Edinburgh University Press, Edinburgh 1878.

More H., The Immortality of the Soul, ed. A. Jacob, Martinus Nijhoff Publishers, Dordrecht 1987.

Newman W., Alchemical Atoms or Artisan "Building Blocks"? A Response to Klein, Perspectives on Science 17(2009)2, 212-229.

Newton I., Matematyczne zasady fllozofii przyrody, tłum. z ang. J. Wawrzycki, Copernicus Center Press, Kraków 2011.

Newton I., O ciężkości i równowadze cieczy, tłum. z ang. A. Grzeliński w: Empiryczne podstawy i obrzeża filozofii XVII wieku, red. B. Grabowska, A. Grzeliński, J. Żelazna, WN UMK, Torun 2014.

Newton I., Of nature's obvious laws and processes in vegetation, http://webapp1. dlib.indiana.edu/newton/mss/norm/ALCH00081/query/field1=text1=of $\% 20$ natures\%20obvious\%201aws

Newton I., Unpublished Scientific Papers of Isaac Newton. A Selection from the Portsmouth Collection in The University Library, Cambridge, ed. and trans. A. R. Hall and M. Boas Hall, Cambridge University Press, Cambridge - London - New York - Melbourne 1978.

Newton I., Issac Newton's Papers and Letters on Natural Philosophy and related documents, red. I.B. Cohen, Harvard University Press, Cambridge, Massachusetts 1958.

Newton I., Opticks: or, A Treatise of the Reflections, Refractions, Inflections and Colours of Light, Printed for William Innys, London 1730.

Nerwton and Religion. Context, Nature and Influence, red. J.E. Force, R.H. Popkin, Kluwer Academic Publishers, Dordrecht 1999. 
Plotyn, Enneady, t.II, tłum. z grec. A. Krokiewicz, Państwowe Wydawnictwo Naukowe, Kraków 1959.

Principe L.M., Alchemy Restored, Isis 102(2011)2, 305-312.

Reid J., The Metaphysics of Henry More, Springer, Dordrecht Heidelberg - New York - London 2012.

Swieżawski S., Dzieje filozofii europejskiej XV wieku, t. 3, ATK Collectanea Theologica, Warszawa 1978.

Ward R., The Life Of Henry More, red. S. Hutton, C. Courtney, M. Courtney, R. Crocker, A.R. Hall, Springer Science+Business Media, Dordrecht 2000.

Westfall R.S., Never at Rest: A Biography of Isaac Newton, Cambridge University Press, Cambridge - London - New York 1980.

\title{
HENRY MORE AND ISAAC NEWTON ON THE ACTIVITY OF MATTER - NEOPLATONIC CONTEXT
}

\begin{abstract}
One of the main challenges for 17th-century natural philosophers was to find an answer to the question of what makes matter active at all? The legacy of 'prime matter' and its pure potentiality was still alive, and the adoption of corpuscular or atomistic theories did not change much here, the conviction about the total passivity of bodies was still dominant. Their actions demanded some explanation that would be the equivalent of an Aristotelian, non-material and active form. It seems that one of the philosophical traditions that were sought for such an explanation was the emanational metaphysics of Plotinus. In seventeenth-century systems it underwent various modifications, but its main idea, indicating the active role of certain 'principles' or 'spirits' responsible for initiating any changes in matter and managing them in accordance with the Creator's intention, remained the foundation of the theories of matter. An example of such solutions are the systems of Henry More and his good acquaintance from Cambridge, Isaac Newton. In the first case there is no doubt about the fundamental influence of Neoplatonism, but in the second case historians' opinions are divided. Newton reaches in search of 'active principles' for alchemical research, with the hope of finding these principles not only when referring to philosophical speculations, but also to experimental methods. This difference, however, does not change the fact that both philosophers try to discover the mode of action of 'active spirits', hesitating between placing in the particles of matter a number of separate principles and pointing to only one acting universally principle that was just an extension of God's arm - More calls it the Spirit of Nature (Vicarious Power of God), and Newton sees that principle ultimately in Christ (Viceroy of God).
\end{abstract}

Keywords: matter, motion, active principles, God, Neoplatonism, alchemy, Henry More, Isaac Newton 


\section{DARIUSZ KUCHARSKI}

d.kucharski@uksw.edu.pl

Uniwersytet Kardynała Stefana Wyszyńskiego w Warszawie, Instytut Filozofii Wóycickiego 1/3, 01-938 Warszawa

DOI: 10.21697/spch.2018.54.4.01 